\title{
Krzysztof Hauke
}

Uniwersytet Ekonomiczny we Wrocławiu

e-mail: krzysztof.hauke@ue.wroc.pl

ORCID: 0000-0002-7966-0428

\section{DZIALANIA INNOWACYJNE W DOMACH KULTURY W UJĘCIU MODELOWYM}

\section{INNOVATIVE ACTIVITIES AT CENTERS OF CULTURE IN A MODEL CONTEXT}

\author{
DOI: $10.15611 /$ ie. 2018.2 .03 \\ JEL Classification: H890, M200, O300, O310, O320
}

Streszczenie: Domy kultury to instytucje kultury, które w dobrowolny sposób powinny jednoczyć członków społeczeństwa informacyjnego przez wspólne zainteresowania. Poprzez działania w sekcjach, grupach zainteresowań tworzą się więzi społeczne. Jednak działania ukierunkowane na odbiorców społeczeństwa informacyjnego muszą w dzisiejszych czasach być innowacyjne. W artykule na podstawie przeprowadzonych badań zostanie zaproponowany ogólny model funkcjonowania domu kultury, który będzie określany jako innowacyjny. Badanie aktualnego stanu domów kultury polegało na przeanalizowaniu bieżących publikacji na temat ich funkcjonowania. Jednak to analiza zawartości informacyjnej stron WWW, bezpośrednia obserwacja, wywiady z pracownikami domów kultury, łącznie z ofertą, jaka jest skierowana do odbiorcy, przyczyniły się do wykreowania modelu współczesnego domu kultury. W kreowaniu tego modelu zostanie wykorzystane zarządzanie procesowe, przemysły kreatywne i technologia ICT.

Słowa kluczowe: domy kultury, innowacyjność, kreatywność, przemysły kreatywne, zarządzanie procesowe.

Summary: Centers of culture are cultural institutions that should voluntarily unite members of the information society through common interests. The potential of cultural houses in shaping social attitudes is difficult to determine. Social ties are created through activities in sections and interest groups. However, activities targeting recipients of the information society have to be innovative at present. Innovative activities in culture centers as of today are not conducted as in other areas of impact. Business without innovation could not function. A consumer is being offered new products or services. In public institutions one can see the understanding of the concept of innovation, which can be applied to local government units, schools and health care institutions. In the chapter, based on the conducted research, a general model of the functioning of a cultural center will be proposed, described as innovative. Process management, creative industries and ICT will be used to create this model.

Keywords: centres of culture, innovation, creativity, creative industries, cultural centers, process management. 


\section{Wstęp}

Instytucje kultury w społeczeństwie informacyjnym mają szczególne znaczenie. Dzięki nim członkowie społeczeństwa mogą realizować swoje potrzeby, które nie wymagają od nich zaangażowania czynnika materialnego w postaci pieniądza. Instytucje kultury mogą rozwijać zainteresowania odbiorców, kształtować poczucie piękna (malarstwo, muzyka, sztuki sceniczne), rozwijać fizycznie, na przykład przez taniec, uczyć gry na instrumentach muzycznych itp. Jednak najważniejszy element, na jaki należy zwrócić uwagę, to tworzenie więzów społecznych. W dzisiejszym skomercjalizowanym biznesie pracowników łączą przede wszystkim procesy, w których muszą uczestniczyć z racji wykonywanych zadań na poszczególnych poziomach zarządzania. Domy kultury są przykładem instytucji kultury, które powinny być tym integratorem społecznym, a wynikiem ich działań ma być spełnianie potrzeb niematerialnych odbiorcy. Jednak analizując działania, z jakimi mamy do czynienia w domach kultury, można odnieść wrażenie, że ich rozwój zatrzymał się kilka lat temu. Odbiorcy, przenosząc swoje doświadczenia z innych obszarów oddziaływania, chcą, aby domy kultury także miały charakter innowacyjny. W realizacji postulatu innowacyjności w domach kultury przeszkadzają ograniczenia finansowe. $\mathrm{Z}$ racji tego, że należą one do instytucji publicznych, finansowanie ich działalności w 98\% jest pokrywane ze środków budżetowych jednostek samorządowych, na których dany dom kultury jest położony terytorialnie. Organizacje o charakterze biznesowym, aby mogły konkurować, muszą stosować coraz to nowe mechanizmy, które będą określały ich poczynania jako innowacyjne.

$\mathrm{W}$ artykule na podstawie przeprowadzonych badań zostaną wskazane mechanizmy, za pomocą których domy kultury będzie można określać mianem innowacyjnych domów kultury. Innowacyjność domów kultury budowana jest przez przemysły kreatywne, zarządzanie procesowe i technologię ICT.

Celem jest zaproponowanie ogólnego modelu funkcjonowania domu kultury. Do stworzenia modelu wykorzystano metodę badawczą w postaci studiów źródeł literaturowych, przede wszystkim raportów, i doświadczenia autora związane z możliwościami współczesnej ICT, ich wpływem na kreowanie innowacyjności w przemysłach kreatywnych oraz zastosowaniem w procesie zarządzania podejścia procesowego. Bardzo ważnym elementem w kreowaniu modelu domu kultury były wywiady bezpośrednie z pracownikami domów kultury. Umiejętne połączenie tych elementów pozwoliło opracować koncepcję modelowego domu kultury, który będzie spełniał oczekiwania członków społeczeństwa informacyjnego.

\section{Innowacyjność w organizacjach}

Innowacyjność to zagadnienie, które musi być realizowane we wszystkich sferach oddziaływania odbiorcy. Trudno sobie wyobrazić współczesny biznes ukierunkowany na odbiorcę, który nie uwzględniałby innowacyjności w swoich działaniach. 
Poprzez innowacyjność organizacje o charakterze biznesowym, dostarczając konsumentowi produkt lub usługę, mogą prowadzić działania konkurencyjne pomiędzy sobą. Współczesny konsument wręcz żąda, aby produkty czy też usługi były innowacyjne w szerokim znaczeniu. Może to być innowacyjność wynikająca z technologii czy sposobu dostarczenia produktu.

Aby organizacje mogły się rozwijać w celu realizacji potrzeb społecznych, muszą być innowacyjne. Kreowanie innowacji możliwe jest dzięki innowacyjności, czyli skłonności oraz zdolności do tworzenia nowych, doskonalenia istniejących produktów i procesów technologicznych. Innowacyjność obejmuje także kreowanie nowych systemów organizacji i zarządzania [Marciniak 2010, s. 27].

Współczesne definiowanie innowacyjności i innowacji opiera się na teorii Schumpetera. Teorię innowacyjności można określić mianem „3I”. Składa się ona z następujących etapów:

- inwencji (invention) - jest to wynik konstruktywnego działania człowieka, który wykorzystuje wiedzę i doświadczenie,

- innowacji (innovation) - zastosowanie nowej koncepcji, wprowadzenie nowego pomysłu do realizacji,

- imitacji (imitation) - upowszechnienie innowacji w otoczeniu (rys. 1).

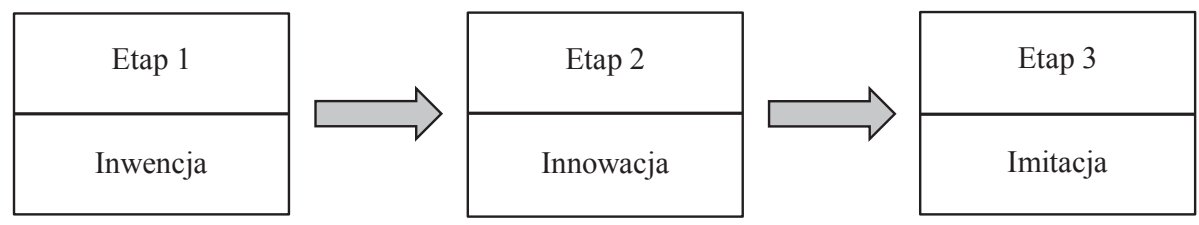

Rys. 1. „3I” Schumpetera

Źródło: opracowanie własne na podstawie [Schumpeter 1960, s. 104-117].

Na podstawie powyższej krótkiej charakterystyki można stwierdzić, że innowacja jest to etap przejściowy pomiędzy inwencją a imitacją i ma charakter jednostkowy. Jeśli innowacja zostanie wdrożona i uzyskiwane są kolejne mutacje przedsięwzięcia, to nie może być traktowana jako działanie innowacyjne. Schumpeter innowację traktuje jako:

- wprowadzanie do produkcji wyrobów nowych lub doskonalenie już istniejących,

- wprowadzanie nowego lub udoskonalenie sposobu produkcji wyrobu,

- otwarcie nowego rynku zbytu,

- zastosowanie nowego sposobu sprzedaży wyrobów lub zakupu surowców do produkcji,

- zastosowanie nowych surowców lub półfabrykatów,

- wprowadzanie nowej organizacji produkcji [Schumpeter 1960, s. 322].

Pojęcie innowacji ma wiele kontekstów znaczeniowych. Najczęściej jest ona definiowana jako nowość, wprowadzenie nowego produktu, usługi (podejście twarde) 
lub procesu (podejście miękkie) [Kopaliński 1999, s. 338]. Człowiek, mając wiedzę teoretyczną lub praktyczną, potrafi coś nowego tworzyć. Umiejętność analitycznego myślenia, a czasem przypadek lub zbieg okoliczności połączony ze sferą nauki pozwala urzeczywistniać i rozpowszechniać nowości [Duraj, Papiernik-Wojdera 2010, s. 61].

Innowacja powoduje zmiany w wyrobach lub procesie wytwarzania. Innowacje najczęściej pozytywnie wpływają na odczucia konsumenckie odbiorców, przez co konsumenci takie podejście odbierają jako działania o wysokim poziomie nowoczesności i konkurencyjności w skali makro.

Dokonując podziału innowacji ze względu na kryterium powstawania czegoś nowego, należy stwierdzić, że innowacje mogą mieć dwa źródła (rys. 2): wewnętrzne i zewnętrzne [Niedzielski i in. 2007, s. 13-14]. Do źródeł wewnętrznych zaliczmy:

- własną działalność badawczo-rozwojową,

- prowadzenie badań marketingowych,

- stwarzanie warunków do kreowania innowacyjności,

- stosowanie technik grupowego rozwiązywania problemów, np. burzy mózgów.

Do źródeł zewnętrznych zaliczamy:

- wyniki badań naukowych,

- zakup licencji,

- transfer technologii,

- wspólne przedsięwzięcia wielu organizacji,

- wiedzę pozyskaną z aktualnych publikacji, konferencji, seminariów naukowych,

- uczestnictwo w targach i wystawach,

- pozyskiwanie nowych pracowników,

- doradztwo firm konsultingowych,

- stosowanie narzędzi porównawczych - benchmarking [Nowacki 2010, s. 31].

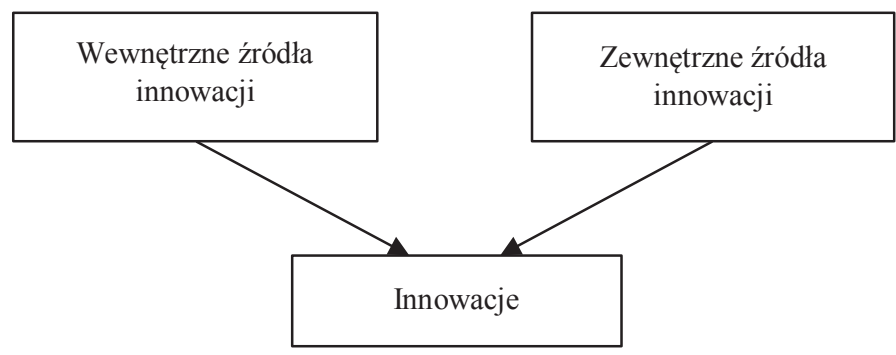

Rys. 2. Źródła innowacji w organizacji

Źródło: opracowanie własne na podstawie [Niedzielski i in. 2007, s. 13-14].

Współczesne organizacje niezależnie od misji, jakie realizują dla odbiorcy, muszą ustawicznie prowadzić działania innowacyjne. Dzięki takim działaniom organizacje będą osiągały przewagę konkurencyjną, co w przypadku biznesu ukierun- 
kowanego na zysk jest bardzo ważne. Podobne działania na szerszą skalę powinny być prowadzone także $\mathrm{w}$ instytucjach publicznych. W tym przypadku nie można w sposób bezpośredni mierzyć efektów taką samą miarą jak w organizacjach o charakterze biznesowym.

\section{Przemysły kreatywne}

Przemysły kreatywne stały się integralną częścią społeczeństwa informacyjnego. Nie tylko oferowane dobra materialne czy świadczone usługi stanowią o podstawowym bycie odbiorcy. Współczesny odbiorca oczekuje nie tylko doznań wynikających z bezpośredniego zakupu produktów lub usług. Chce on realizować swoje zainteresowania, uprawiać hobby, kreatywnie spędzać wolny czas. Definicja przemysłów kreatywnych jest przedmiotem wielu opracowań naukowych. Jednak kolejne podejścia do tego terminu nie wnoszą wartości dodanej. Podstawowa definicja przemysłów kreatywnych została wypracowana w roku 1998 przez brytyjski Department for Digital, Culture, Media \& Sport (DCMS). Przemysły kreatywne są to takie, które mają swoje źródło w indywidualnej kreatywności, umiejętnościach i talencie oraz mają potencjał tworzenia wartości poprzez generowanie i eksploatację własności intelektualnej.

Do przemysłów kreatywnych zalicza się:

- reklamę,

- sztuki wizualne,

- dzieła sztuki i antyki,

- dziedzictwo kulturowe,

- architekturę,

- rzemiosło artystyczne,

- design,

- przemysł filmowy,

- interaktywne oprogramowanie służące rozrywce (gry komputerowe),

- muzykę,

- $\quad$ sztuki performatywne ${ }^{1}$,

- przemysł wydawniczy,

- telewizję i radio [Zawadzki 2016].

Wśród cech wyróżniających przemysły kreatywne odnoszących się do obszarów oddziaływania wyróżnia się:

- produkty, usługi, procesy - są wynikiem działań intelektualnych człowieka,

- środowisko pracy zawodowej - odnosi się do pracy umysłowej, która może mieć charakter pracy indywidualnej lub zespołowej,

- podatność na zmiany produktu - produkty z grupy tak zwanych nowych technologii są bardzo podatne na zmiany, których oczekują odbiorcy, bądź są jego wyobraźnią,

\footnotetext{
${ }^{1}$ Sztuka opierająca się na grze aktorskiej w szerokim rozumieniu.
} 
- instytucje, firmy, organizacje - funkcjonowanie ich jest bardzo silnie związane z ustawicznym procesem dostosowywania się do oczekiwań odbiorcy (konsumenta),

- poniesione nakłady i uzyskane wyniki w ujęciu ekonomicznym - wszelkie innowacje związane są z nakładami finansowymi, które jest trudno oszacować, a jeszcze trudniej określić, jakie będą efekty działań innowacyjnych będących wynikiem umysłu człowieka [Klasik 2009, s. 33-34].

Przemysły kreatywne w gospodarce konkurencyjnej mogą stanowić ważny element innowacyjności organizacji. Ustawicznie realizowane cele specyficzne dla rozwoju tych przemysłów w dłuższej perspektywie czasowej będą w organizacjach narzędziem do oferowania atrakcyjnych dla odbiorców dóbr w postaci usług lub produktów. Organizacje niezależnie od misji, jaką realizują, muszą prowadzić swoją działalność w taki sposób, aby znaczyć swoją pozycję na rynku i utrzymać jej poziom.

\section{Domy kultury jako przedmiot badań}

Dom kultury (cultural establishment) to instytucja związana z obszarem kultury, która prowadzi działalność społeczno-kulturalną ukierunkowaną na realizację potrzeb zainteresowanych ludzi. Siedzibę stanowią pomieszczenia wzniesione specjalnie dla tych placówek lub są one adaptowane. Najczęściej jest to kilka pomieszczeń odpowiednio wyposażonych, w których prowadzone są specjalistyczne zajęcia. Dodatkowo domy kultury mają też większą salę widowiskowo-kinową [www1].

Dom kultury (ośrodek kultury, centrum kultury) ${ }^{2}$ - jest to pojęcie szersze ze względu na organizację. Ma rozwijać zainteresowania ludzi i prowadzić szeroko rozumianą działalność w obszarze społecznym i kulturalnym. W domach kultury mogą alokować się następujące instytucje, np.:

- biblioteka,

- filharmonia, orkiestra,

- galeria sztuki,

- kino, instytucja filmowa,

- muzeum,

- ognisko artystyczne,

- opera, operetka,

- teatr,

- ośrodek badań i dokumentacji.

W domach kultury mogą mieścić się:

- lokale kulturalno-rozrywkowe,

- sale teatralno-kinowe,

${ }^{2}$ Instytucja kultury - zakład o charakterze publicznym zajmujący się upowszechnianiem kultury, może być zarówno państwowy, jak i samorządowy. Działalność reguluje ustawa z dnia 25 października 1991 r. o organizowaniu i prowadzeniu działalności kulturalnej [www3]. 
- czytelnie,

- świetlice.

W domach kultury prowadzone są pozaszkolne inicjatywy dydaktyczno-kulturalne dla młodzieży lub działalność dla dorosłych, np.:

- koła zainteresowań,

- przedstawienia,

- warsztaty kulturalne,

- wystawy,

- zabawy.

Z punktu widzenia obszaru terytorialnego dom kultury swoim obszarem obejmuje: osiedla, miasta $\mathrm{i}$ wsie, mając w swoim zakresie działań promować kulturę danego obszaru [www2].

W zakresie obszarów zadaniowych gminy realizowane są działania publiczne, przede wszystkim dotyczące społeczności lokalnej i zgodne z ogólnie przyjętą polityką rozwoju danej społeczności, na podstawie różnych zapisów wynikających $\mathrm{z}$ ustaw lub przepisów mających uwarunkowania prawne. Między innymi uchwalone normy prawne dotyczą kształtowania i zadań kultury skierowanej na społeczeństwo lokalne; zapisane są w art. 7 ust. 1 pkt 9 ustawy z dnia 8 marca 1990 r. o samorządzie gminnym. Jednostki samorządowe na poziomie gminy traktowane są jako w pełni samodzielne i mogą realizować zadania na własną odpowiedzialność, mając do dyspozycji odpowiedni fundusz finansowy [www4].

Zgodnie z treścią art. $85 \mathrm{i}$ art. 86 ustawy o samorządzie gminnym nadzór nad działalnością gminy sprawowany jest na podstawie kryterium zgodności z prawem. Organami uprawnionymi do sprawowania nadzoru nad samorządem gminnym są Prezes Rady Ministrów i wojewoda, a w zakresie spraw finansowych - regionalna izba obrachunkowa.

Organizowanie i prowadzenie działalności kulturalnej gmin jest traktowane jako zadanie własne i mające obowiązkowy charakter. Wynika to wprost z ustawy z dnia 25 października 1991 r. o organizowaniu i prowadzeniu działalności instytucji kultury.

Działalność kulturalna w rozumieniu niniejszej ustawy polega na tworzeniu, upowszechnianiu i ochronie kultury. Państwo sprawuje mecenat nad działalnością kulturalną polegający na wspieraniu i promocji twórczości, edukacji i oświaty kulturalnej, działan i inicjatyw kulturalnych oraz opieki nad zabytkami. Minister właściwy do spraw kultury i ochrony dziedzictwa narodowego może wspierać finansowo, w ramach mecenatu państwa, realizację planowanych na dany rok zadań związanych z polityką kulturalną państwa, prowadzonych przez instytucje kultury i inne podmioty nienależące do sektora finansów publicznych.

Jak już wspomniano, na podstawie art. 9 ust. 1 ustawy gminy muszą (jest to traktowane jako jeden z celów statutowych gminy) organizować i prowadzić działalność kulturalną między innymi przez domy kultury na swoim terenie. Niezapewnienie funkcjonowania tego typu instytucji naraża gminy na naruszenie prawa o samorządzie terytorialnym i niewypełnienie jednej z podstawowych jej funkcji na potrzeby lokalnej społeczności. 
Gmina jest zobligowana do powołania domów kultury. Powołanie domu kultury skutkuje wpisem do rejestru i wtedy uzyskuje on osobowość prawną. Oznacza to między innymi, że dom kultury prowadzi samodzielnie działania finansowe i jest za to w pełni odpowiedzialny pod rygorem wynikającym z prawa. Inną konsekwencją uzyskania osobowości prawnej jest to, że gmina nie może w dowolny sposób zmieniać charakteru i sposobu finansowania domu kultury. Funkcjonowanie tych domów z racji swojej misji musi być w znacznej części lub w całości wspierane przez gminę. Gmina musi partycypować w działaniach finansowych domów kultury. Jest to zapisane w art. 12 ustawy. Oczywiście domy kultury mogą wspomagać się środkami finansowymi od bezpośrednio zainteresowanych lub samodzielnie pozyskiwać środki finansowe z różnego rodzaju programów rozwojowych. Jednak brak jest mechanizmów, które zmuszałyby domy kultury do takiego działania [www4].

$\mathrm{Z}$ mocy prawa wynika, że gmina nie odpowiada za zobowiązania instytucji kultury, z zastrzeżeniem art. 24 i 25 tej ustawy (art. 14 ust. 1 i 2). Szczegółowe zasady finansowania kultury na poziomie lokalnym zostały określone w rozdziale 3 ustawy.

Zadania domów kultury to:

- budowa kapitału ludzkiego,

- budowa kapitału relacyjnego społeczności lokalnej,

- nawiązywanie komunikacji międzyludzkiej,

- zmniejszanie różnic intelektualnych pomiędzy członkami społeczności,

- kreowanie postaw społecznych (współpraca pomiędzy jednostkami ludzkimi),

- kształtowanie potencjału intelektualnego regionów,

- pielęgnowanie tożsamości kulturowej, narodowej, norm etycznych danej zbiorowości społecznej, która zamieszkuje obszar gminy,

- integrowanie i pielęgnowanie więzi lokalnej społeczności,

- ograniczanie rozwoju patologii społecznej,

- przeciwdziałanie wykluczeniu społecznemu,

- ustawiczny rozwój intelektualny społeczeństwa.

W Polsce według stanu na początek 2018 roku jest około 4400 domów kultury (tab. 1). Należy podkreślić, że są to tylko te placówki kultury, które w nazwie mają wyraźne określenie „dom kultury”.

Analiza danych liczbowych (tab. 1) wskazuje, że w województwach: dolnośląskim, lubelskim, lubuskim, mazowieckim, małopolskim i śląskim liczba mieszkańców na jeden dom kultury wynosi powyżej 10000 mieszkańców. Z kolei w województwie opolskim liczba mieszkańców przypadająca na 1 dom kultury to poniżej 5000 mieszkańców. Liczba mieszkańców na jeden dom kultury może świadczyć o dużej rozpiętości liczbowej. W skrajnym przypadku jest to 4648 (woj. zachodniopomorskie) i 12088 (woj. mazowieckie) na jeden dom kultury. Analiza powierzchni województwa $\mathrm{w} \mathrm{km}^{2}$ przypadająca na jeden dom kultury w skrajnych przypadkach to: minimum 29,09 $\mathrm{km}^{2}$ (woj. śląskie), maksimum 160,09 km² (woj. warmińsko-mazurskie). Ta analiza pozwala na wyciągnięcie wniosku, że względy historyczne i kulturowe, z jakimi mamy do czynienia w Polsce, doprowadzily do istnienia takiej liczby domów kultury w poszczególnych województwach. 
Tabela 1. Domy kultury w Polsce w ujęciu liczbowym

\begin{tabular}{|c|c|c|c|}
\hline Województwo & $\begin{array}{l}\text { Liczba } \\
\text { domów } \\
\text { kultury }\end{array}$ & $\begin{array}{l}\text { Powierzchnia w } \mathrm{km}^{2} \\
\text { na jeden dom kultury }\end{array}$ & $\begin{array}{l}\text { Liczba mieszkańców } \\
\text { przypadająca na jeden } \\
\text { dom kultury }\end{array}$ \\
\hline Dolnośląskie & 280 & 71,24 & 10372 \\
\hline Kujawsko-pomorskie & 229 & 78,48 & 9110 \\
\hline Lubelskie & 204 & 123,15 & 10488 \\
\hline Lubuskie & 94 & 148,81 & 10830 \\
\hline Łódzkie & 270 & 67,48 & 9235 \\
\hline Mazowieckie & 279 & 54,42 & 12088 \\
\hline Małopolskie & 498 & 71,40 & 10741 \\
\hline Opolskie & 214 & 43,98 & 4654 \\
\hline Podkarpackie & 358 & 49,85 & 5943 \\
\hline Podlaskie & 177 & 114,05 & 6716 \\
\hline Pomorskie & 250 & 73,24 & 9230 \\
\hline Śląskie & 424 & 29,09 & 10780 \\
\hline Świętokrzyskie & 128 & 91,49 & 9821 \\
\hline Warmińsko-mazurskie & 151 & 160,09 & 9534 \\
\hline Wielkopolskie & 476 & 62,66 & 7301 \\
\hline Zachodniopomorskie & 368 & 62,21 & 4648 \\
\hline
\end{tabular}

Źródło: opracowanie własne na podstawie [www5].

Kolejna analiza pokazuje, jaka jest liczba domów kultury w siedzibach województw (rys. 3). W przypadku województwa kujawsko-pomorskiego i lubuskiego do analizy były brane 2 miasta ze względu na to, że w jednym z nich swoją siedzibę ma ogólnie wojewoda, a w drugim sejmik wojewódzki i urząd marszałkowski. Jest to wynik zaszłości historycznych. Najwięcej domów kultury (68) jest w Krakowie, najmniej (6) zaś w Opolu, czyli w Krakowie jest ponad 11 razy więcej domów kultury niż w Opolu. Jeśli dodatkowo analiza będzie dokonana przez pryzmat liczby mieszkańców: 128142 (I kwartał 2017 roku) - Opole, 767348 (31 XII 2017) Kraków, to w Krakowie mieszka 6,5 razy więcej mieszkańców niż w Krakowie. Trudno wprost wyjaśnić takie dysproporcje. Wniosek - położenie geograficzne nie ma wpływu na ścisłą korelację pomiędzy liczbą domów kultury w miastach wojewódzkich z liczbą mieszkańców czy gęstością zaludnienia. Jak już wspomniano, wytłumaczyć to można tylko historią regionu, polityką ukierunkowaną na rozwój danych regionów kraju.

Rysunek 3 obrazuje liczbę domów kultury w poszczególnych miastach wojewódzkich.

Kolejna analiza dotyczy liczby domów kultury w poszczególnych województwach. W województwie małopolskim jest najwięcej (498) domów kultury. Niewiele 


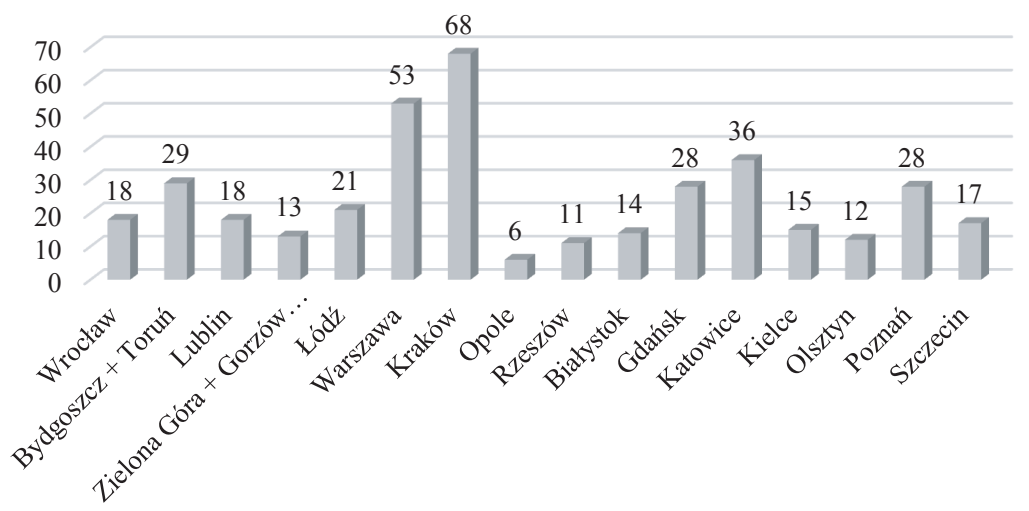

Rys. 3. Domy kultury w miastach wojewódzkich

Źródło: opracowanie własne na podstawie [www5].

mniej (476) jest domów kultury w województwie wielkopolskim. Powyżej 400 domów kultury jest jeszcze w województwie śląskim (424). Z kolei najmniej (94) jest ich w województwie lubuskim (rys. 4).

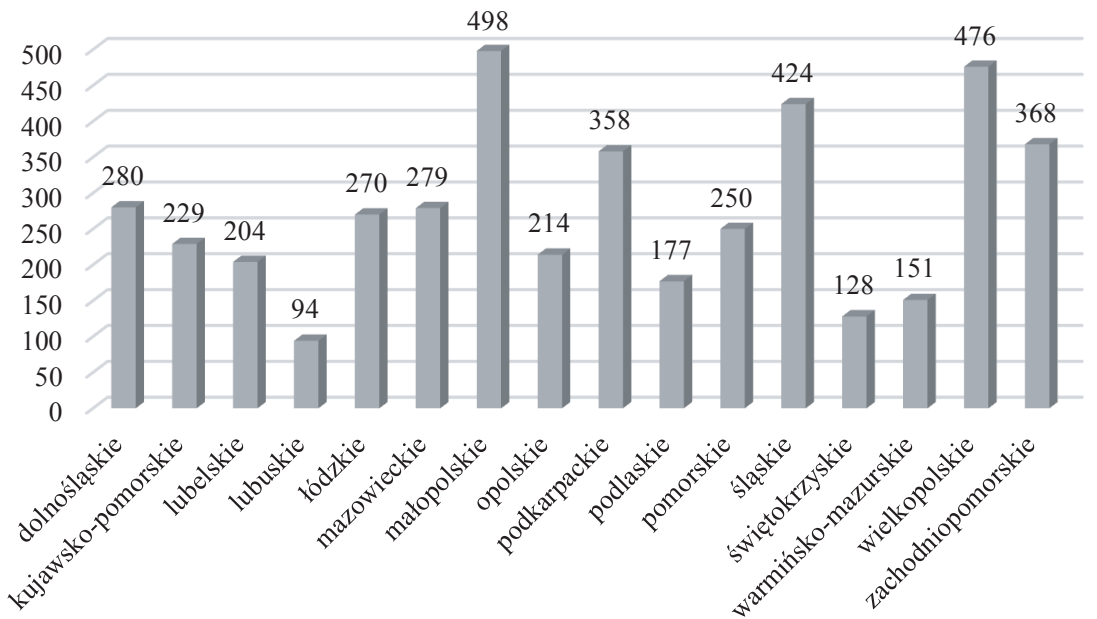

Rys. 4. Domy kultury w poszczególnych województwach

Źródło: opracowanie własne na podstawie [www5].

Ogólna charakterystyka domów kultury pokazuje, na jaką skalę makro należy prowadzić działania o charakterze innowacyjnym. Potencjał domów kultury, który pozwoli w przyszłości wykorzystać innowacyjność przede wszystkim dzieci oraz młodzieży, jest $\mathrm{w}$ tej chwili niedoceniony i trudny do oszacowania. Jedno jednak 
należy stwierdzić, że prowadzenie innowacyjności ad hoc w organizacji może za jakiś czas być nieskuteczne. Należy poszukiwać kreowania innowacyjności poprzez kreowanie właściwych postaw od najmłodszych lat w społeczeństwie. Domy kultury mogą wypełnić tę lukę. Skutków należy upatrywać dopiero za jakiś czas.

\section{Model innowacyjnego domu kultury}

W organizacjach należy uaktywniać wszystkie mechanizmy, które będą powodowały, że odbiorcy będą odczuwali zmiany, oraz w ich ocenie będą zaspokajały ich potrzeby zgodnie z rozwojem całego otoczenia. Rozwój technologii, kreowanie nowych modeli zachowań, dbałość o psychikę to tylko niektóre czynniki, które odbiorca chce przenosić na wszystkie sfery oddziaływania. Organizacja musi prowadzić działania innowacyjne ukierunkowane na realizację koncepcji doskonalenia. Stosowana w organizacjach filozofia kaizen ${ }^{3}$, wywodząca się z Japonii, zrewolucjonizowała jakość dóbr oferowanych przez firmy. Podejście kaizen to ciągły i ustawiczny proces doskonalenia wszystkiego, co może wpływać na końcowy kształt dobra. Akceptacja oferowanego dobra dla konsumenta będzie stanowiła o sukcesie ekonomicznym organizacji nie tylko w wymiarze ekonomicznym. Na każdym etapie zarządzania procesowego realizowanego $\mathrm{w}$ czasie musi być stosowane podejście kaizen. Bowiem zadowolenie organizacji z tytułu oferowanego dobra i akceptacji przez odbiorcę może mieć charakter krótkookresowy. Zaniechanie ustawicznego podnoszenia jakości może doprowadzić w skrajnym przypadku do wyeliminowania z rynku poczynań organizacji, szczególnie jeśli organizacja ma charakter typowo biznesowy, która realizuje swoje działania w celu realizacji funkcji zysku. Domy kultury mają charakter instytucji, które nie generują zysku. Można jednak na dzień dzisiejszy zauważyć skostniały system zarządzania tymi instytucjami. Wynika to przede wszystkim z zaszłości historycznych i niezrozumienia zmieniającego się otoczenia.

Aby społeczeństwo w dalszym ciągu chciało korzystać z działalności domów kultury, muszą one stać się innowacyjne, tak jak to jest widoczne w instytucjach komercyjnych. Domy kultury muszą postawić sobie nowe cele o charakterze innowacyjnym i je skutecznie z determinacją realizować.

Określenie celów pozwoli na przygotowanie założeń do modelowego ujęcia działalności domów kultury. Innowacyjny dom kultury powinien:

- być otwarty na potrzeby mieszkańców społeczności lokalnej,

- być otwarty na pomysły ze strony mieszkańców gminy,

${ }^{3}$ Kaizen - japońskie słowo o podwójnym znaczeniu:

- oznaczające po polsku: poprawę, polepszenie, zmianę na lepsze,

- oznaczające japońską filozofię biznesową (sposób postępowania) ustawicznego polepszania, poprawiania procesu zarządzania i produkcji na wszystkich jego szczeblach, z uwzględnieniem między innymi technik biznesu ,just-in-time" [https://pl.wikipedia.org/wiki/Kaizen (data dostępu: 8.04.2018)]. 
- kształtować postawy odpowiedzialności za realizację pomysłów społeczności lokalnej,

- dostrzegać, pielęgnować i kształtować postawy społeczne o dużym potencjale,

- adaptować się do potrzeb społecznych,

- wskazywać kierunki rozwoju otoczenia i wspomagać w procesie dostosowywania się do zmian, szczególnie w obszarze nowych technologii,

- dostosowywać ofertę do zapotrzebowania społecznego,

- być otwartym na każdego członka społeczeństwa informacyjnego, bez względu na wiek, płeć, poglądy polityczne, wyznanie wiary, rasę,

- być platformą wymiany wiedzy pomiędzy członkami społeczeństwa informacyjnego,

- współpracować z różnymi instytucjami kultury i otoczeniem biznesowym (dobre praktyki, forum wymiany wiedzy wynikającej z uwarunkowań otoczenia, wzajemna pomoc),

- funkcjonować zgodnie z normami prawnymi,

- wspierać aktywność społeczeństwa jako całości,

- mieć dyrektora, który będzie menedżerem domu kultury,

- mieć kadrę, która dynamicznie dostosuje się do nadchodzących zmian,

- ustawicznie szkolić kadrę merytoryczną domu kultury,

- odgrywać rolę edukacyjną,

- kreować postawy potrafiące funkcjonować w sieci,

- być miejscem integracji społecznej,

- kształtować nie tylko postawy konsumpcyjne, ale także uczyć wrażliwości na piękno (podejście w kierunku działań artystycznych) [Szczurek i in. 2017, s. 28]. Innowacyjność $\mathrm{w}$ domach kultury może być realizowana trzema niezależnymi kanałami (rys. 8): implementując ideę przemysłów kreatywnych (rys. 5), wdrażając nowe technologie z obszaru ICT (rys. 6), stosując zarządzanie procesowe w zarządzaniu domami kultury (rys. 7). Potencjał, jaki mają wyszczególnione kanały, pozwala uczynić domy kultury innowacyjnymi instytucjami, które zaspokajać będą potrzeby niematerialne odbiorców.

Przemysłów kreatywnych nie można rozpatrywać oddzielnie w stosunku do reszty gospodarki, ponieważ towarzyszy im wiele innych, ważnych wymiarów:

- dodają wartość innym sektorom, szczególnie poprzez design, reklamę i branding,

- należą do największych pracodawców zatrudniających pracowników o wysokich kwalifikacjach, stając się tym samym częścią ,gospodarki opartej na wiedzy", a więc tą częścią gospodarki, która zatrudnia utalentowanych absolwentów wyższych uczelni,

- przyczyniają się do rewitalizacji małych i dużych miast,

- łączą ludzi z wykształceniem policealnym i wyższym i współpracują z nimi,

- zacieśniają więzy między ludźmi i społecznościami dzięki wspólnym doświadczeniom [BOP Consulting 2010, s. 18]. 
Dla domów kultury przemysły kreatywne nabierają szczególnego znaczenia. To przede wszystkim w tego typu placówkach kulturalnych można rozwijać i pielęgnować przemysły kreatywne (rys. 5). Na dzień dzisiejszy coraz więcej organizacji biznesowych korzysta z wytworów przemysłów kreatywnych. Organizacje biznesowe stają się innowacyjne dzięki tym przemysłom kreatywnym.

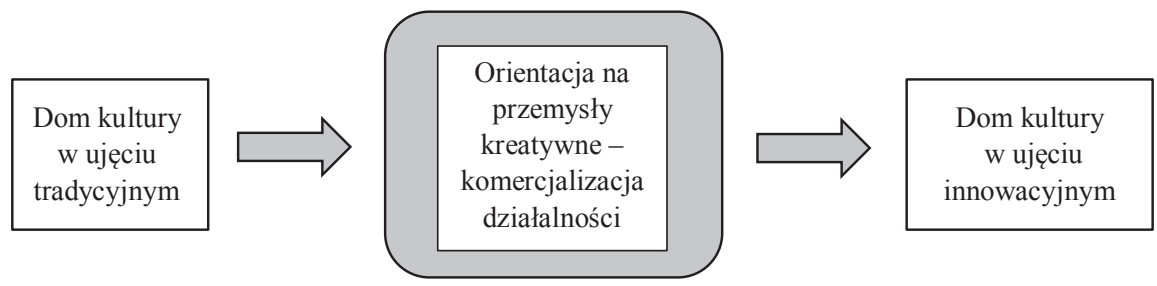

Rys. 5. Przemysły kreatywne w innowacyjnych domach kultury

Źródło: opracowanie własne.

Rozwiązania sprzętowe i programowe technologii ICT (rys. 6):

- chmura obliczeniowa,

- hurtownie danych,

- systemy klasy Business Intelligence,

- Big Data,

- systemy zdalnego nauczania,

- chatbot,

- telepraca,

- aplikacje mobilne,

- rozwiązania ICT dla niepełnosprawnych.

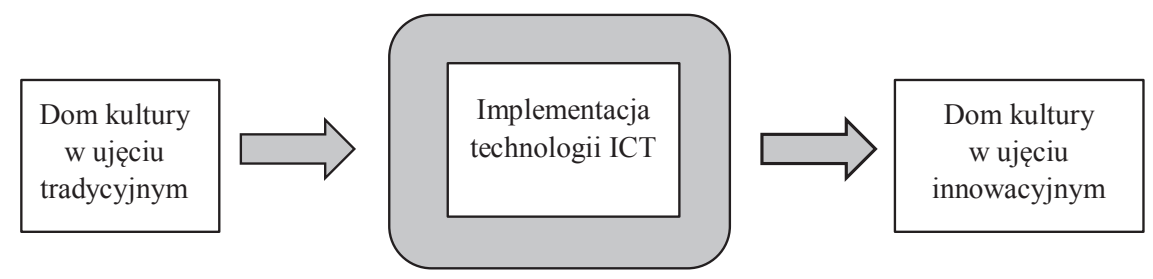

Rys. 6. Technologia ICT w innowacyjnych domach kultury

Źródło: opracowanie własne.

Wyspecyfikowanie procesów realizowanych w domach kultury pozwoli na wprowadzenie zarządzania procesowego (rys. 7), które może mieć wpływ na kreowanie innowacyjności. Przykłady realizacji procesów w domach kultury w ujęciu innowacyjnym:

- określenie czytelnych celów w domach kultury, 
- określenie potrzeb domu kultury wynikających z adaptowania do nowych warunków otoczenia,

- opracowanie modelu pracy pracowników, w którym kluczową rolę będą odgrywały efekty (uzyskane wartości dodane),

- podniesienie jakości pracy w domach kultury,

- szybkie reagowanie na potrzeby społeczne, które mogą być realizowane w domach kultury,

- uporządkowanie działań statutowych w domach kultury,

- uporządkowanie struktury organizacyjnej domów kultury,

- uproszczenie procedury pozyskiwania środków finansowych z różnych programów rozwojowych,

- wdrożenie modelu działania domu kultury reagującego w czasie rzeczywistym na sygnały pochodzące $\mathrm{z}$ otoczenia,

- współpraca pomiędzy różnymi podmiotami otoczenia.

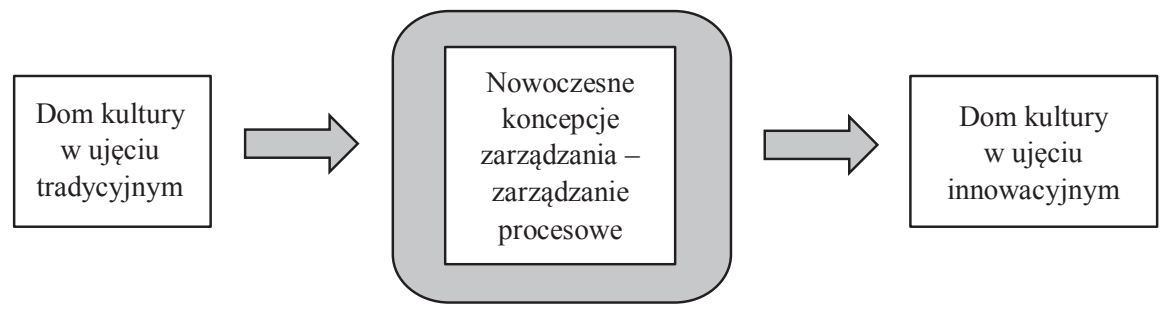

Rys. 7. Zarządzanie procesowe w innowacyjnych domach kultury

Źródło: opracowanie własne.

Modelowy dom kultury w ujęciu innowacyjnym (rys. 8):

- stosuje w procesie zarządzania podejście procesowe,

- jest orientowany na przemysły kreatywne,

- stosuje rozwiązania współczesnej ICT.

Modelowy dom kultury w ujęciu innowacyjnym powinien (rys. 9):

- być otwarty na zmiany,

- być tolerancyjny na zmiany postawy społecznej w wyniku zastosowania nowych technologii,

- kreować postawy aktywnego działania społeczeństwa,

- kształtować postawę społeczności lokalnej,

- mieć możliwość nawiązywania kontaktów z artystami uważanymi za wzór do naśladowania, co wpłynie pozytywnie na rozwój społeczeństwa lokalnego,

- mieć umiejętność budowy strategii rozwoju domu kultury,

- posiadać umiejętność funkcjonowania w ramach określonych ograniczeń,

- przyczyniać się do zmiany wizerunku gminy w kontekście dynamicznych zmian zachodzących w otoczeniu, 


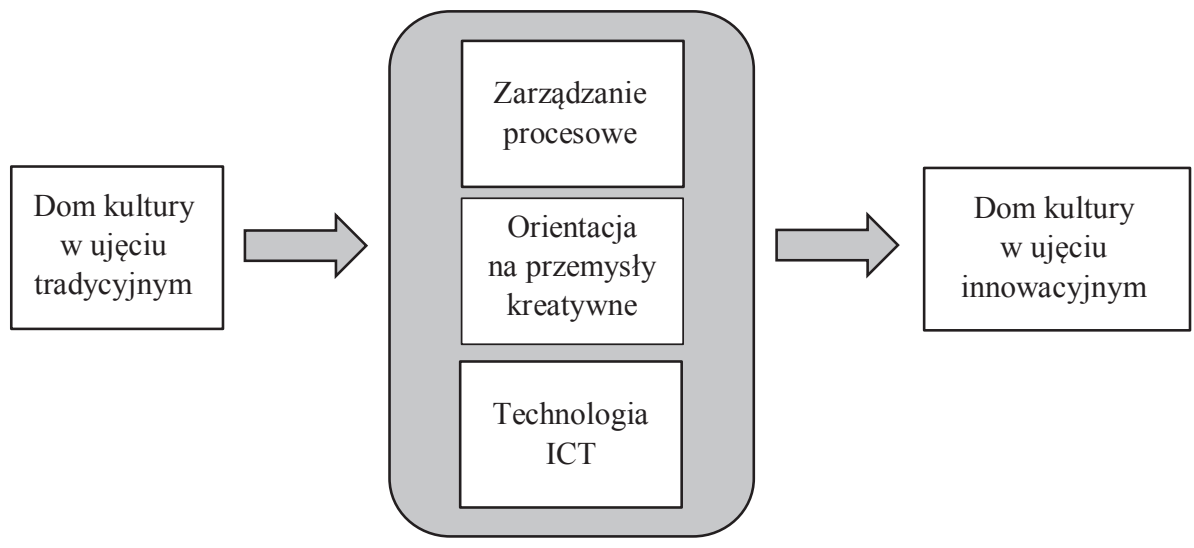

Rys. 8. Od tradycyjnego do innowacyjnego domu kultury

Źródło: opracowanie własne.

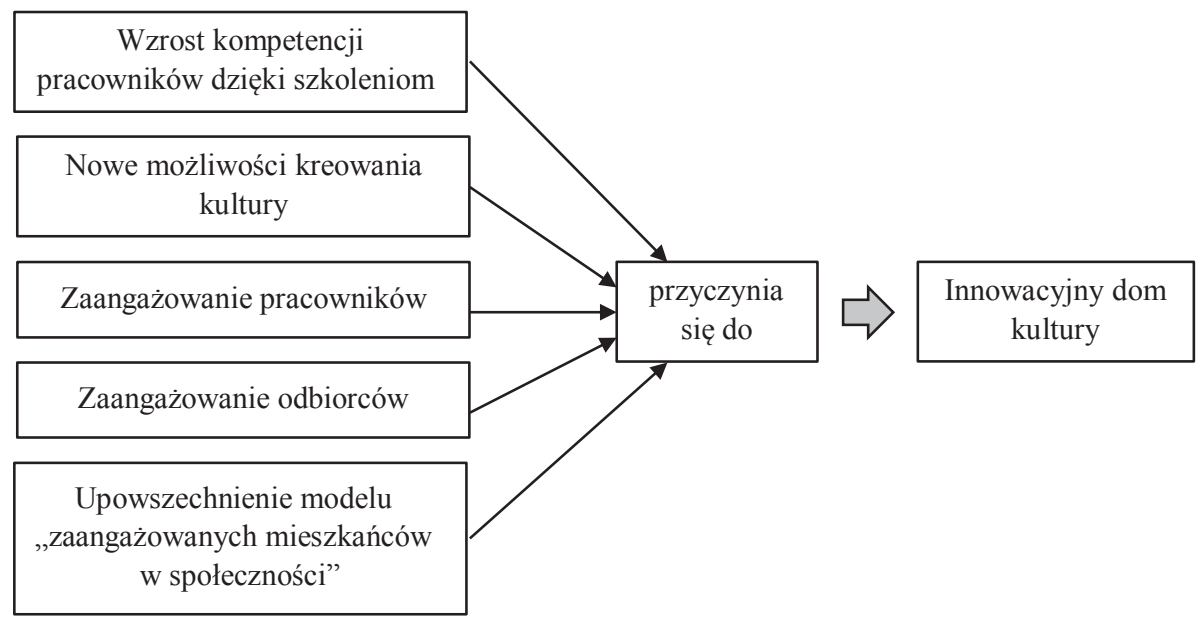

Rys. 9. Innowacyjność domów kultury w ujęciu podmiotowym

Źródło: opracowanie własne na podstawie [Szczurek i in. 2017, s. 29].

- stanowić ważny element w życiu danej społeczności lokalnej,

- stanowić wyznacznik w kształtowaniu postaw społeczności lokalnej,

- stwarzać warunki do kształtowania postaw społecznych,

- uwzględniać w swoich działaniach wszystkich członków społeczności bez żadnych ograniczeń,

- zmniejszać skalę wykluczenia społecznego. 
Spodziewane efekty implementacji modelu domu kultury, dzięki zastosowaniu nowych rozwiązań technologii ICT, uwzględniające zagadnienia przemysłów kreatywnych i zarządzania procesowego to:

- pojawienie się w danej społeczności nowych sposobów zarządzania instytucją domu kultury,

- kreowanie postawy działań innowacyjnych w domach kultury,

- doskonalenie samooceny i roli pracowników domu kultury w rozwoju kapitału intelektualnego społeczeństwa,

- transparentne formy współpracy domów kultury z mieszkańcami danej społeczności,

- nawiązanie współpracy z różnymi instytucjami zewnętrznymi i przedsiębiorcami,

- podniesienie wartości instytucji kultury w postaci domów kultury w kreowaniu innowacyjności.

Domy kultury, aby mogły dalej funkcjonować i sprzyjać rozwojowi odbiorców, muszą zmienić swoje podejście do turbulentnego otoczenia. Tylko działania o charakterze innowacyjnym pozwolą na zdynamizowanie oddziaływania na otoczenie.

\section{Zakończenie}

Współczesne zarządzanie organizacjami to nieustanny proces dostosowywania do potrzeb odbiorców. Odbiorca wraz ze swoim rozwojem odczuwa coraz to wyższe potrzeby, i to nie tylko materialne w postaci produktu czy usługi. Można to określić jako twarde zaspokajanie potrzeb konsumenta. Ważne są potrzeby niematerialne, które gwarantują warunki egzystencjalne w postaci miejsca zamieszkania, zapewnienie bezpieczeństwa, dostęp do placówek służby zdrowia, możliwość ustawicznego kształcenia przez całe życie, dostęp do instytucji kultury. W tym przypadku można te potrzeby określić jako miękkie (rys. 10).

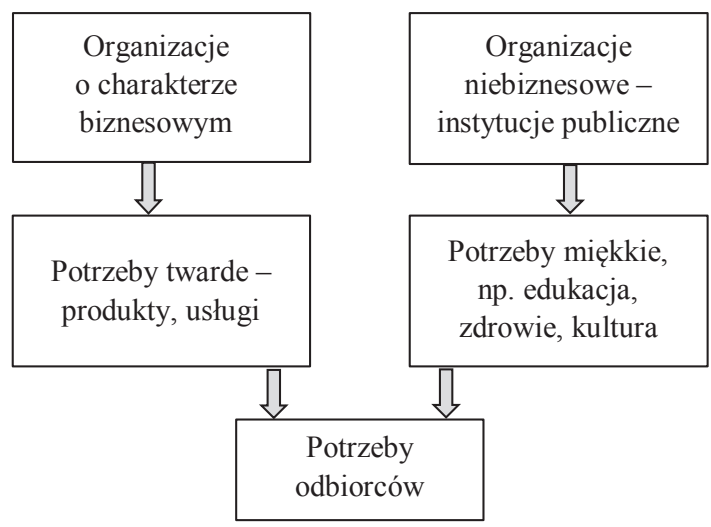

Rys. 10. Potrzeby odbiorców w społeczeństwie informacyjnym

Źródło: opracowanie własne. 
Dodatkowym elementem rozróżniającym jest okres, w jakim dana potrzeba jest realizowana przez odbiorcę. Niezależnie od roli potrzeby w odczuciach odbiorcy nie można założyć sobie stałości. Odbiorca jest coraz bardziej wymagający, obserwuje otoczenie, kształci się i stąd potrzeba pozyskania coraz to nowych, lepszych, doskonalszych produktów zadowolenia odbiorców. Organizacje o charakterze biznesowym cały czas prowadzą działania innowacyjne. Chcąc przetrwać na rynku, muszą ustawicznie obserwować poczynania organizacji realizujących potrzeby z tego samego obszaru. Organizacje o charakterze niebiznesowym, gdzie przykładem są domy kultury, takich działań o charakterze innowacyjnym jeszcze nie prowadzą. To wynika przede wszystkim z misji, jakie mają do spełnienia. Dodatkowo z racji tego, że stanowią one segmenty instytucji publicznych, sposób zarządzania jest mocno scentralizowany i działania są finansowane ze środków publicznych. Niezależnie od tego, w jaki sposób organizacje angażują się w oferowane potrzeby, muszą one być innowacyjne czy też kreatywne.

Zaproponowane podejście $\mathrm{w}$ ujęciu modelowym pozwoli na uatrakcyjnienie oferty domów kultury. Domy kultury mogą stać się innowacyjne, co w dłuższej perspektywie czasowej będzie przekładać się na działania innowacyjne w biznesie. W domach kultury należy upatrywać źródeł zachowań ludzi, z których mogą w przyszlości korzystać organizacje biznesowe, aby być innowacyjne. W przyszłości należałoby przeprowadzić badania, czy i w jaki sposób instytucje kultury w postaci domów kultury przyczyniają się do rozwoju innowacyjności organizacji biznesowej.

\section{Literatura}

BOP Consulting, 2010, Kreatywna Gospodarka i Przemysly Kultury (Creative and Cultural Economy), Część 2. Mapowanie sektorów kreatywnych: narzędzia, British Council.

Duraj J., Papiernik-Wojdera M., 2010, Przedsiębiorczość i innowacyjność, Difin, Warszawa.

Klasik A., 2009, Przemysty kreatywne oparte na nauce i kulturze, [w:] Kreatywne miasto - kreatywna aglomeracja, red. A. Klasik, Prace Naukowe Akademii Ekonomicznej im. K. Adamieckiego w Katowicach, Katowice.

Kopaliński W., 1999, Podręczny słownik wyrazów obcych, Oficyna Wydawnicza Rytm, Warszawa.

Marciniak S., 2010, Innowacyjność i konkurencyjność gospodarki, Wydawnictwo C.H. Beck, Warszawa.

Niedzielski P., Markiewicz J., Rychlik K., Rzewuski T., 2007, Innowacyjność w działalności przedsiębiorstw. Kompendium wiedzy, Wydawnictwo Uniwersytetu Szczecińskiego, Szczecin.

Nowacki R., 2010, Zarzadzanie - konkurencyjność - innowacyjność, [w:] Nowacki R. (red.), Innowacyjność w zarzadzaniu a konkurencyjność przedsiębiorstwa, Difin, Warszawa, s. 15-46.

Schumpeter J.A.,1960, Teoria rozwoju gospodarczego, Wydawnictwo Naukowe PWN, Warszawa.

Szczurek A., Pogoda I., Leszczyńska M., Szostakowska M., Tomczak B., 2017, Raport końcowy Badanie ewaluacyjne programu Dom Kultury+: Dom Kultury+ 2010-2011 oraz Dom Kultury+ Inicjatywy Lokalne 2013, 2014, 2015, 2016, Ośrodek Ewaluacji ASM - Centrum Badań i Analiz Rynku Sp. z.o.o., Warszawa.

Zawadzki K., 2016, Praca i wynagrodzenia w gospodarce kreatywnej. Uwarunkowania - specyfikaewolucja, Wydawnictwo Naukowe Uniwersytetu Mikołaja Kopernika, Torun. 


\section{Źródla internetowe}

www1: https://stat.gov.pl/metainformacje/slownik-pojec/pojecia-stosowane-w-statystyce-publicznej/ 65, pojecie.html (data dostępu: 25.04.2018).

www2: https://pl.wikipedia.org/wiki/Dom_kultury (data dostępu: 25.04.2018).

www3: https://pl.wikipedia.org/wiki/Instytucja_kultury (data dostępu: 25.04.2018).

www4: http://samorzad.infor.pl/temat_dnia/409722,Status-prawny-instytucji-kultury.html (data dostępu: 17.05 .2018$)$.

www5: http://www.nck.pl/ (data dostępu: 24.03.2018). 